\title{
ELIMINATION OF DUTIES IN SEZ IN KALININGRAD REGION
}

N.Volovik

On 1 April 2016, the transition period terminates for a number of enterprises, which exploit preferential customs treatment in trading of goods manufactured in the territory of the Special Economic Zone (SEZ) of the Kaliningrad region to the rest of the territory of Eurasian Economic Union (EEU).

According to the Agreement of 18 June 182010 on issues regarding the free (special, dedicated) economic zones located on the customs territory of the Customs Union and to the customs regime of the special economic zone and to the Federal Law No 16 of 10 January 2016 "On the Special Economic Zone in the Kaliningrad region and Amending Certain Legislative Acts of the Russian Federation", starting from 1 April 2016 expires validity of preferences in trading produced goods from the territory of the Kaliningrad region to the EEU member states for firms eligible for import customs duty exemption. The SEZ residents registered prior to January 1, 2012 the validity of preferences has been extended through 1 April 2017.

According to the Federal law of 22 January 1996 No 13-FZ "On Special Economic Zone in Kaliningrad Oblast" (Law No 13-FZ) commencing from 1996 a Free Economic Zone regime was effective on the territory of the Kaliningrad region, which allowed businessmen to import raw materials and components for finished products from abroad free of customs duties as well as free of non-tariff regulation measures regarding foreign goods and apply preference scheme in trading their produced goods from foreign components if they correspond to sufficient depth of processing to other regions of the Russian Federation. Goods correspond sufficient criteria of processing when one of the following conditions has been met: processing of goods resulted in the change of goods code at the level of any of first four digits or added value of transactions from processing constitutes no less than $30 \%$ of the price of the product.

This Federal law ensured growth of the business activity on the territory of the Kaliningrad region and exerted significant influence on the restructuring of the region's economy: creation and development of new competitive industries (automobile manufacturing, consumer electronics, food processing, cabinet-making, etc.). Around 100 residents are eligible for the SEZ preference regime. The largest are: CJSC "Sodruzhestvo Soya", JSC "Technobalt", CJSC "Alko-Nafta", JSC "Soyuz TTM", CJSC "Balt-Trans", JSC Miratorg West" among other. Total amount of investment made by the SEZ residents in the Kaliningrad region has exceeded $\mathrm{Rb} 90 \mathrm{bn}$. First of all, investments flow into manufacturing industry, transport and communications.

At present, functioning of the Special Economic Zone in the Kaliningrad region is regulated by the Federal law of 10 January 2006 No 16-FZ "On the Special Economic Zone in the Kaliningrad region and Amending Certain Legislative Acts of the Russian Federation" (Law No 16-FZ) which entered into force on 1 April 2006. 
Main difference between Law No 16-FZ and Law No 13-FZ lies in the change in the principal mechanism of the SEZ regulation: set by the Law No 13-FZ 1996 customs preferences are replaced by tax privileges for the SEZ residents.

Resident of the Special Economic Zone (Resident) is a legal person, meeting the Law No 16-FZ requirements and included in the General Register of residents of the Special Economic Zone (the Register). In order to be included in the Register of the SEZ residents, the legal person must implement in the territory of the Kaliningrad region the investment project to the tune of $\mathrm{Rb} 150$ bn of investments. The investment project must be completed during the period not exceeding three years from the date the legal person was included in the Register.

The majority of businesses registered as the SEZ residents implement the investment projects in manufacturing industries, transport as well as sphere of transactions with real estate, lease and provision of services.

The SEZ residents enjoy the following significant tax privileges:

- in accordance with Article 288.1 of the Tax Code of the Russia Federation, for the first six years commencing from the date of inclusion of the legal person in the Register of the SEZ residents, the tax rate on corporate income obtained from the investment project is at $0 \%$. For the period from the seventh through twelfth year the tax allowance to the tune of $50 \%$ is provided from the corporate income tax set in p. 1 Article 284 of the Tax Code (20\%);

- in accordance with Article 385.1 of the Tax Code of the Russian Federation, for the first six calendar years commencing from the date of inclusion of the legal person in the Register of the SEZ residents, the property tax rate in the Kaliningrad region on the property of organization created or purchased during the realization of the investment project is set at $0 \%$. For the period from the seventh trough twelfth year the tax allowance to the tune of $50 \%$ is provided from the property tax rate set by the law of the Kaliningrad region.

Other taxes and charges are paid in compliance with the effective legislation of the Russian Federation on taxes and charges.

Following entry into force of the Law No 16-FZ, from 1 April 2006, all legal persons and individual entrepreneurs registered in the Kaliningrad region and acting pursuant to the Law No 13-FZ a ten-year long transition period was given. During the transition period these legal persons still enjoyed preferences envisaged by the Law No 13-FZ, i.e. operated in the free customs zone regime. For example, main volume of customs declarations account for "the free customs zone" regime $(55.1 \%$ of the total volume of customs declarations). Second place was taken by customs declarations made in 'reimport' regime (33.5\%) when declarations for goods subject to sufficient processing in the territory of the Kaliningrad SEZ and traded to the rest of the EEU territory are accounted. Goods subject to 'domestic consumption' took the third place (6.6\%).

On 1 April 2016, terminates the transition period for businesses, which use customs preferences in trading goods produced in the territory of the Kaliningrad region SEZ to the remaining EEU territory. In practice, this means that after the mentioned date the vast majority of the regional participants of the economic activity and producers will not be eligible to trade customs free to the remaining EEU territory goods subject to sufficient processing in the territory of the SEZ of the Kaliningrad region. Meanwhile, preferences envis- 
aged by the Law No 16-FZ remain: foreign goods still can be imported to the territory of the Kaliningrad region free of customs duties, taxes and traded (interchange) in the territory of the region without restrictions.

According to the data made a point at the meeting of the Government committee on socio-economic development of the Kaliningrad region held on 26 February 2016, elimination of preferential customs treatment will affect 785 companies, which employ $24 \%$ of total number employed in the regional economy (around 50 thousand persons). These companies account for $22 \%$ of gross regional product.

Functioning of the Special Economic Zone in the Kaliningrad region should remain the main driver for the development of the region. That is why the elimination of preferential customs treatment will be compensated the region by the Federal center. This issue has been discussed since 2014. In late 2014, the Government of the Russian Federation adopted a Regulation No 1210 of 15 November 2014 "On Approval of Methodology for Calculation Subject to Compensation Amounts of Customs Duties, Taxes and Directive on Establishment of Fact for Increasing Amounts of Customs Duties, Taxes or Creation of Obligation for Payment Customs Duties, Taxes", which establishes order for calculation and receiving compensation for costs incurred by payment of customs duties, taxes in the SEZ in the Kaliningrad region.

In 2015, the Government of the Russian Federation adopted Resolution No 471 of 15 May 2015 “On Approval of Rules for Granting Interbudgetary Transfers from the Federal Budget to the Budget of the Kaliningrad Region for Compensation of Amounts of Customs Duties, Taxes while Establishing Fact for Increasing Amounts of Customs Duties, Taxes or Creation of Obligation for Payment Customs Duties, Taxes" and Resolution No 1275 of 29 November 2015 "On Granting from the Federal Budget to the Budget of the Kaliningrad Region other Interbudgetary Transfers to Ensure Support of Legal Persons and Residents of the Special Economic Zone Acting in the Territory of the Kaliningrad Region." Compensation customs duties amounts will permit to maintain existing business environment and minimize feasible losses by exclave economy after the elimination of preferential customs treatment starting from 1 April 2016.

In 2016, the amount of subsidies will total Rb $66.7 \mathrm{bn}$. Solely residents of the Kaliningrad Special Economic Zone will be subject for the federal subsidy, who preserved the number of employed personnel, wages and salaries and the level of investments as well as free of debt before the tax and customs bodies prior to and after 2016. In this regard, while preparing application for federal assistance enterprises indicate the number of employees, provide proof of lack of debt on taxes to the budget and extra budgetary funds and take obligation to maintain these and other key parameters of their activity. According to preliminary estimate, around 800 enterprises and organizations of the Kaliningrad region are eligible for this financial assistance. Commencing with 2020, the size of the subsidy will be falling by $5 \%$ annually, which should contribute restructuring of the regional economy.

The Ministry of Economy of the Kaliningrad region forecasts economic recession by $4.5 \%$ in 2016 , relying on assistance promised by the federal authorities to enterprises operating within the "transition period."

In early 2016, the RF government continued preparation of normative and legal decisions aimed at supporting the economy of the Kaliningrad region. The Federal law No 70-FZ of 11 March 2016 introduced amendments in 
Article 4 of the Law Bo 16-FZ, which envisage reduction from Rb $150 \mathrm{mn}$ to $\mathrm{Rb} 50 \mathrm{mn}$ the minimum volume of capital investment required to obtain the status of the resident of the Special Economic Zone in the Kaliningrad region in case of realization of investment projects in the sphere of tourism and recreation, health resort activity, disease prevention, medical rehabilitation, fishing and agriculture.

On 22 March 2016, the State Duma deputies approved in second and third (final) reading law "On Amending the Second Part of the Tax Code of the Russian Federation Regarding Termination of the Free Customs Regime in the Territory of the Special Economic Zone in the Kaliningrad Region", which gives Kaliningrad taxpayers 180 day VAT deferment and provides mechanism for further offset of VAT payment on goods sold in the Russian territory.

Taking into account special importance of the complex socio-economic development of the Kaliningrad region as geostrategic region of Russia, by the commission of the RF President, the Ministry of Economy is developing a draft federal law "On socio-economic development of the Kaliningrad region", according to which the Special Economic Zone in the Kaliningrad region will be transferred into regime similar to the territories with priority development.

At the same time, residents of the Special Economic Zone will be given a possibility to reregister with retaining existing privileges and preferences as well as their extension according to privileges envisaged for the territory with priority development. Also is envisaged a regime of simplified or visa-free for foreign nationals to the territory of the region for the purposes of tourism, health resort treatment as well as creation of free port in the territory of the Kaliningrad region. 